(Journal of Civil Engineering, Building and Transportation)

\title{
Prediksi Penurunan Konsolidasi Tanah Lunak Dengan Metode Analitis Dan Metode Element Hingga
}

\section{Prediction of Soft Soil Consolidation Settlement Using Analitycal Method and Finite Element Method}

\author{
Rudianto Surbakti \\ Program Studi Teknik Sipil, Fakultas Teknik \\ Universitas Medan Area, Indonesia \\ *Corresponding Email: ruri.syahid@gmail.com, rudianto@staff.uma.ac.id.
}

\begin{abstract}
Abstrak
Penurunan tanah, pergerakan tanah dan pergeseran tanah adalah masalah yang paling sering dihadapi ketika membangun konstruksi diatas lapisan tanah lunak. Tanah dengan konsistensi lunak memiliki tingkat penurunan tanah yang tinggi. Terdapat banyak metode yang dikembangkan untuk memprediksi besar total penurunan konsolidasi yang terjadi, diantaranya metode analitis dengan menggunakan teori yang dikembangkan Terzaghi atau metode element hingga menggunakan software Plaxis 2D dan 3D. Sebagai pembanding kedua metode tersebut diperlukan data harian penurunan tanah yang terjadi di lapangan dicatat dari settlement plate yang dipasang di lapangan. Analisis ini bertujuan untuk memprediksi penurunan tanah yang terjadi di lapangan menggunkan metode Terzaghi dan metode elemen hingga secara dua dimensi dan tiga dimensi. Melalui metode analitis Terzaghi diperoleh hasil prediksi penurunan tanah -6,218 meter, dengan metode elemen hingga menggunakan plaxis 2D adalah $-6,404$ meter dan plaxis 3D adalah $-6,356$ meter. Sedangkan penurunan yang terjadi menurut pengamatan settlement plate di lapangan adalah -6,320 meter. Sehingga dapat disimpulkan prediksi penurunan konsolidasi menggunakan pemodelan Plaxis 3D memberikan hasil yang lebih mendekati penurunan hasil observasi di lapangan dibandingkan pemodelan Plaxis 2D dan metode analitis Terzaghi.
\end{abstract}

Kata Kunci: Konsolidasi, Metode Elemen Hingga, Terzaghi, Penurunan Tanah

\begin{abstract}
Land subsidence, ground movement and ground displacement are the most common problems encountered when constructing construction on soft soil layers. Soils with soft consistency have a high rate of soil settlement. There are many methods developed to predict the total consolidation settlement that occurs, including analytical methods using the theory developed by Terzaghi or the finite element method using Plaxis 2D and 3D software. As a comparison between the two methods, daily data on land subsidence that occurs in the field is recorded from the settlement plate installed in the field. This analysis aims to predict land subsidence that occurs in the field using the Terzaghi method and the finite element method in two dimensions and three dimensions. Through the Terzaghi analytical method, the prediction results for soil settlement are -6.218 meters, the finite element method using $2 D$ plaxis is -6.404 meters and $3 D$ plaxis is -6.356 meters. While the decrease that occurred according to observations of settlement plate in the field was -6,320 meters. So it can be concluded that the prediction of consolidation settlement decline using Plaxis 3D modeling gives results that are closer to the settlement by observations in the field than Plaxis 2D modeling and Terzaghi analytical methods.
\end{abstract}

Keywords: Consolidastion, Finite Element Method, Terzaghi, Soil Settlement

How to Cite: Surbakti, R. (2021). Prediksi Penurunan Konsolidasi Tanah Lunak Dengan Metode Analitis Dan Metode Element Hingga. JCEBT (Journal of Civil Engineering, Building and Transportation). 5 (2): 83 - 91 


\section{PENDAHULUAN}

Tanah lunak umumnya memiliki sifat kompresibilitas yang tinggi, permeabilitas yang rendah, penurunan konsolidasi yang besar, sudut geser dalam tanah dan daya dukung yang rendah. Hal ini membuat tanah lunak membutuhkan penanganan khusus ketika ingin membangun konstruksi diatasnya. Faktor-faktor yang menyebabkan tanah lunak memiliki karakteristik buruk adalah karena tanah ini memiliki kadar air yang tinggi, ukuran butiran yang kecil serta gradasi butiran yang buruk. Penurunan tanah merupakan masalah besar dalam kestabilan konstruksi, oleh karena itu diperlukan perhitungan yang akurat untuk memprediksi besaran penurunan tanah lunak yang akan terjadi.

Untuk memperbaiki tanah lunak salah satu caranya adalah dengan memperkecil angka pori tanah dengan mengeluarkan air porinya. Namun untuk tanah dengan permeabilitas rendah diperlukan penambahan instrument geoteknik untuk mempercepat pengaliran airnya. Penambahan PVD untuk menaikkan permeabilitas tanah dan penambahan beban preloading merupakan salah satu metode yang umum digunakan untuk menangani tanah-tanah lunak. Metode pembebanan awal (preloading) dan drainase vertikal mampu untuk meningkatkan kekuatan geser tanah lunak dan mengeluarkan air pori dalam tanah dengan waktu yang lebih singkat. Yun Tae kim dkk (2017) telah melakukan pengujian kenaikan kecepatan tanah dengan pemasangan PVD, hasilnya menunjukkan PVD mampu mempercepat konslidasi tanah secara signifikan.

Metode yang umum dipakai untuk memprediksi besarnya penurunan tanah diantaranya adalah metode analitis konsolidasi satu dimensi Terzaghi (1943). Pada perkembangannya dibuatlah progam yang mampu memprediksi penurunan tanah dengan metode elemen hingga yaitu program Plaxis. Program Plaxis mampu menyediakan berbagai analisa teknik tentang perpindahan dan penurunan tanah, tegangan-tegangan yang bekerja dan potensi keruntuhan pada tanah. Program ini tersedia dalam bentuk 2 dimensi dan 3 dimensi yang dirancang untuk membat geometri struktur dan lapisan tanah yang akan dianalisa. Program ini membutuhkan geometri dari konstruksi yang akan dianalisa, data-data laboratorium baik data indek maupun engineering properties dari lapisan tanah tersebut. Pada penelitian ini yang menjadi studi kasus adalah proyek reklamasi Belawan yang memiliki lapisan tanah lunak mencapai lebih dari 44 meter dari data SPTnya. 
Pada penelitian sebelumnya Hasbullah Nawir dkk (2012) telah melakukan evaluasi terhadap penurunan tanah pada proyek di Bontang Kalimantan Timur. Pada penelitian ini dibandingkan presiksi penurunan antara metode satu dimensi yang dikembangkan Terzaghi (1943), metode observasi yang dikembangkan Asaoka (1978) dan metode elemen hingga menggunakan plaxis 2D. Hasilnya penelitiannya menunjukkan bahwa metode observasi dengan teori Asaoka lebih mendekati penurunan aktual lapangan dibandingkan metode element hingga menggunakan plaxis dan konsolidasi satu dimensi Terzaghi. Namun metode Asaoka ini memiliki kelemahan yaitu hanya bisa perhitungkan ketika proses konsolidasi berlangsung bukan untuk perencanaan, sehingga keluaran penelitiannya adalah waktu kapan penurunan tanah akan berhenti.

Pada penelitian lainnya Agung Prekoso dkk (2019) telah melakukan penelitian prediksi penurunan tanah pada timbunan proyek jalan ruas GiriwoyoDuwet dengan membandingkan antara metode elemen hingga menggunakan plaxis 2D yang mana hasilnya terdapat penurunan sebesar $1,104 \mathrm{~cm}$, metode teoritis yang dikembangkan Timonshenko dan Goodier terdapat penurunan sebesar 1,896 cm dibandingkan dengan penurunan aktual lapangan yaitu sebesar $3 \mathrm{~cm}$. Penelitian ini menyimpulkan bahwa penurunan dari teoritis lebih mendekati lapangan dibandingkan dengan plaxis 2D. Melihat penurunan yang terjadi sangat kecil, diperlukan penelitian lain untuk penurunan tanah yang besar. Disisi lain Michael (2017) juga telah melakukan analisis prediksi penurunan tanah dengan metode elemen hingga menggunakan plaxis 2D dan metode analitik terhadap timbunan preloading dan PVD pada ruas jalan bebas hambatan Medan-Kualanamu (KM 36+100). Pada penelitian ini disimpulkan bahwa prediksi penurunan yang diperoleh dari program plaxis lebih mendekati aktual lapangan dibandingkan dengan analitik.

Roesyanto (2017) melakukan penelitian proyek pembangunan runway bandara Kualanamu menggunakan plaxis 2D dengan permodelan mohr coloumb. Hasil permodelan dibandingkan dengan penurunan aktual yang ditinjau langsung di lapangan pada bebrapa titik pemasangan settlement plate. Pada penelitian ini disimpulkan bahwa terdapat perbedaan hasil penurunan tanah aktual lapangan dibandingkan dengan perhitungan Plaxis. Disebutkan perbedaan ini kemungkinan disebabkan data tanah yang diobsevasi tidak mewakili kondisi asli lapangan dikarenakan lokasi 
pengambilan data laboratorium tanah berjauhan dengan lokasi observasi.

Titi Hayati (2018) melakukan analisis terhadap penurunan tanah pada lokasi reklamasi Belawan fase-2 yang berdekatan dengan lokasi penelitian ini. Pada penelitian tersebut tidak terdapat sand replacement pada konstruksi reklamasinya. Pada penelitian ini yang menjadi fokus bahasan adalah pengaruh smear zone terhadap prediksi penurunan tanah, yang mana dihasilkan bahwa perbedaan penurunan dengan metode element hingga menggunakan efek smear zone dengan aktual lapangan adalah sebesar 3,51\% dan plaxis tiga dimensi 3,11\%. Sedangkan jika dilakukan perhitungan tanpa menghitung pengaruh semar zone diperoleh perbedaan penurunan dengan aktual lapangan adalah sebesar 14,86\% dan plaxis tiga dimensi 4,27\%. Hasil dari penelitian tersebut menunjukkan bahwa efek smear zone lebih menggambarkan kondisi aktual tanah setelah terganggu oleh prose pemancangan PVD.

\section{METODE PENELITIAN}

Pada penelitian ini penurunan aktual lapangan akan ditinjau dari data penurunan settlement plate-S13 yang diperoleh dari lapangan dan akan dibandingkan dengan penurunan analitis menggunakan metode Terzaghi dengan metode elemen hingga menggunakan plaxis 2D dan plaxis 3D. Penelitian ini berbeda dengan penelitian-penelitian sebelumnya dimana lokasi penelitian memiliki lapisan tanah lunak yang sangat tebal dimana kedalaman tanah lunak mencapai -44 mLWS. Efek smear zone juga diperhitungkan dalam penelitian ini, sehingga akan diperoleh hasil yang lebih akurat untuk menunjukkan metode mana yang paling mendekati penurunan yang sebenarnya di lapangan.

Pada penelitian ini, yang fokus menjadi tinjauan penelitian adalah lokasi reklamasi yang menggunakan metode prapembebanan (preloading) yang dikombinasikan dengan pemasangan prefabricated vertical drain. Pekerjaan reklamasi ini berdampingan langsung dengan lokasi pengerukan alur pelayaran, sehingga pada pelaksanaan dilakukan pembuatan sand key sebagai penghalang terjadinya kenaikan elevasi tanah dasar pada alur pelayaran.

Sand key adalah lokasi di mana sand replacement dikerjakan, pada lokasi ini tanah lunak akan digali dari elevasi permukaan dasar laut sampai elevasi 19,00 mLWS. Kemudian akan ditimbun kembali menggunakan pasir yang memiliki karateristik baik. Fungsi dari sand replacement ini adalah untuk menahan tekanan lateral yang bergerak 
dari timbunan preloading menuju ke alur pelayaran kapal.

Keseluruhan dimensi geometri diperoleh dari data lapangan dan tahapan timbunan diperoleh dari data pengukuran lapangan. Yang harus diperhatikan adalah tinggi timbunan maksimum dan lama proses per tahap penimbunan preloading serta kemiringan lereng yang terjadi di lapangan. Data tahapan penimbunan layer per layer diperoleh dari laporan pengukuran settlement plate yang terpasang di lapangan.

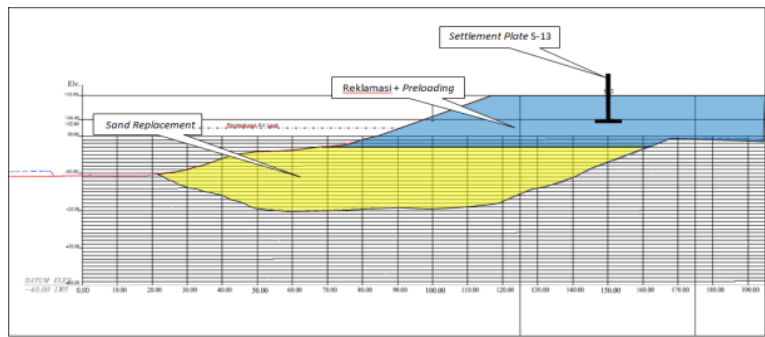

Gambar 1: Potongan melintang lokasi yang dianalisis setelah selesai pekerjaan preloading

Data geometri kemudian dimodelkan dengan menggunakan Plaxis 2D dan 3D seperti yang ditunjukkan pada Gambar 2 dan Gambar 3 berikut:

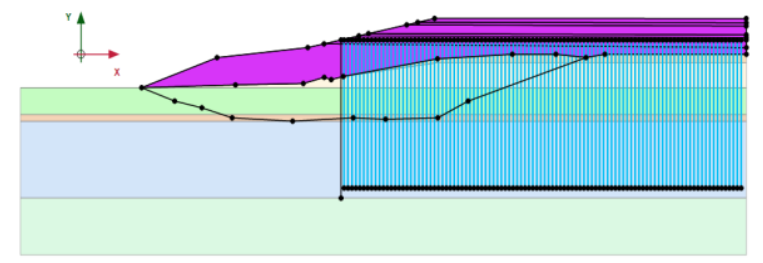

Gambar 2: Permodelan geometeri dengan Plaxis 2D

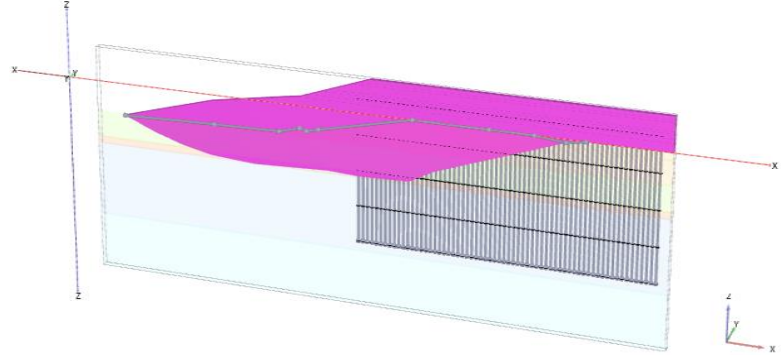

Gambar 3: Permodelan geometeri dengan Plaxis 3D

\section{HASIL DAN PEMBAHASAN}

Besar penurunan konsolidasi maksimum tanah secara analitis dapat dihitung dengan menggunakan teori konsolidasi satu dimensi Terzaghi yaitu dengan menggunakan Persamaan berikut:

$$
\mathrm{s}=\frac{c_{c} H}{1+e_{O}} \log \left(\frac{p_{o(i)}+\Delta p(i)}{p_{O(i)}}\right)
$$

Dari data indeks pemampatan tanah pada titik ini, lapisan tanah dapat dibagi menjadi 4 lapisan dengan data-data tanah setiap lapisannya adalah sepertiyang tertera pada pada Tabel 1:

Tabel 1: Material properties lapisan tanah dasar

\begin{tabular}{|c|c|c|c|c|}
\hline \multirow{2}{*}{$\begin{array}{c}\text { Data } \\
\text { Properties }\end{array}$} & \multicolumn{3}{|c|}{ Lapisan Tanah } & \multirow[b]{2}{*}{$\begin{array}{c}\text { Lapisan } \\
\quad 4 \\
\end{array}$} \\
\hline & $\begin{array}{c}\text { Lapisan } \\
1 \\
\end{array}$ & $\begin{array}{c}\text { Lapisan } \\
2 \\
\end{array}$ & $\begin{array}{c}\text { Lapisan } \\
3 \\
\end{array}$ & \\
\hline $\begin{array}{l}\text { Tebal lapisan } \\
\text { Indeks }\end{array}$ & 7,5 & 10,50 & 25,00 & 17,00 \\
\hline $\begin{array}{l}\text { pemampatan } \\
\left(\mathrm{c}_{\mathrm{c}}\right)\end{array}$ & 0,289 & 1,165 & 1,276 & 0,880 \\
\hline $\begin{array}{c}\text { Angka pori } \\
\left(\mathrm{e}_{\mathrm{o}}\right)\end{array}$ & 1,375 & 3,386 & 2,167 & 1,744 \\
\hline$\gamma_{\text {unsat }}$ & 11,60 & 5,83 & 8,79 & 11,03 \\
\hline$Y_{\text {sat }}$ & 16,30 & 13,10 & 15,30 & 16,80 \\
\hline
\end{tabular}

Penurunan tanah yang terjadi dihitung pada setiap lapisan tanah dengan nilai indeks pemampatan yang berbeda. Dikarenakan penimbunan dilakukan dengan variasi waktu 
yang cukup lama, hal ini menyebabkan selama proses penimbunan tersebut berlangsung telah terjadi konsolidasi pada tanah, maka tekanan efektif overburden untuk tiap tahap penimbunan berbeda. Nilai tekanan efektif untuk setiap tahap penimbunan tanah berikutnya dihitung dengan penambahan tebal tanah timbun sebelumnya. Hasil perhitungannya dapat dilihat pada Tabel 2 berikut ini:

Tabel 2: Hasil pehitungan penurunan tanah secara

analitis

\begin{tabular}{|c|c|c|c|c|c|c|}
\hline \multirow{2}{*}{ Fase timbunan } & \multirow{2}{*}{$\begin{array}{c}\text { Tinggi } \\
\text { timbunan } \\
\text { (meter) }\end{array}$} & \multicolumn{5}{|c|}{ Besar penurunan tanah (meter) } \\
\hline & & $\begin{array}{c}\text { Lapisan } \\
1 \\
\end{array}$ & $\begin{array}{c}\text { Lapisan } \\
2 \\
\end{array}$ & $\begin{array}{c}\text { Lapisan } \\
3 \\
\end{array}$ & $\begin{array}{c}\text { Lapisan } \\
4 \\
\end{array}$ & Jumlah \\
\hline $\begin{array}{l}\text { Reklamasi under } \\
\text { water }\end{array}$ & 2,80 & 0,379 & 0,563 & 1,001 & 0,309 & 2,254 \\
\hline $\begin{array}{c}\text { Reklamasi above } \\
\text { water }\end{array}$ & 1,20 & 0,093 & 0,179 & 0,368 & 0,121 & 0,761 \\
\hline Preloading 1 & 1,50 & 0,092 & 0,192 & 0,420 & 0,143 & 0,847 \\
\hline Preloading 2 & 0,70 & 0,037 & 0,080 & 0,183 & 0,064 & 0,364 \\
\hline Preloading 3 & 2,60 & 0,112 & 0,259 & 0,620 & 0,224 & 1,214 \\
\hline Preloading 4 & 0,80 & 0,029 & 0,070 & 0,174 & 0,065 & 0,338 \\
\hline Preloading 5 & 1,10 & 0,037 & 0,090 & 0,229 & 0,086 & 0,441 \\
\hline \multicolumn{6}{|c|}{ Total penurunan (meter) } & 6,218 \\
\hline
\end{tabular}

\section{Hasil dari permodelan 2D dan 3D}

Untuk menentukan waktu pelaksanaan setiap tahapan pekerjaan lapangan dapat diperoleh dari data pengukuran harian yang terdapat pada settlement plate S-13. Dimana pada data settlement plate selain tercatat penurunan instrument juga tercatat penambahan elevasi tanah timbunan setiap harinya. Dari data ini diketahui berapa lama waktu yang dibutuhkan untuk menaikkan elevasi timbunan pada setiap tahapan pekerjaannya. Tahapan-tahapan pelaksanaan pekerjaannya adalah sebagai berikut :
- Tahap 1: Pekerjaan galian tanah untuk penimbunan sand replacement selama 30 hari

- Tahap 2: Pekerjaan timbunan sand replacement selama10 hari

- Tahap 3: Pekerjaan timbunan under water selama 3 hari

- Tahap 4: pekerjaan timbunan above water selama 3 hari

- Tahap 5: konsolidasi timbunan selama 6 hari

- Tahap 6: pemasangan PVD dan settlement plate selama 10 hari.

- Tahap 7: penimbunan preloading tahap 1 setinggi 1,5 m selama 43 hari.

- Tahap 8: penimbunan preloading tahap 2 setinggi $0,7 \mathrm{~m}$ selama 1 hari.

- Tahap 9: penimbunan preloading tahap 3 setinggi 2,6 m selama 1 hari.

- Tahap 10: penimbunan preloading tahap 4 setinggi 0,8 m selama 1 hari.

- Tahap 11: penimbunan preloading tahap 5 setinggi 1,1 m selama 7 hari.

- Tahap 12: konsolidasi akhir timbunan selama 89 hari.

Dalam permodelan metode elemen hingga dibutuhkan input parameterparameter tanah. Parameter-perameter tanah yang digunakan pada permodelan Plaxis diambil dari hasil pengujian laboratorium. Lapisan-lapisan tanah eksisting yang merupakan tanah lunak (lanau dan lanau kepasiran) memiliki prilaku undrained pada 
beberapa lapisan dan drained pada lapisan lainnya. Sedangkan lapisan timbunan preloading yang merupakan pasir memiliki perilaku drained.

Koefisien permeabilitas tanah baik untuk vertikal maupun horizontal diambil dari hasil laboratorium. Namun untuk lapisanlapisan yang terkena efek smear zone nilai permeabilitas horizontalnya akan dirubah sesuai hasil perhitungan analitis, di mana nilainya akan mengecil akibat pemancangan menggunakan mandrel. Permodelan vertical drain akan digunakan tools vertical drain yang tersedia pada program Plaxis. Lapisan timbunan yang tidak dilewati oleh vertical drain, nilai permeabilitas horizontal dan vertikalnya $\left(k_{x}\right.$ dan $\left.k_{y}\right)$ menggunakan hasil yang diperoleh dari pengujian laboratorium.

Lapisan tanah yang terganggu akibat pemancangan PVD harus dihitung besar efek smear zone terhadap koefisien permeabilitas horizontal tanahnya. Metode yang digunakan dalam perhitungan adalah metode Hird et al (1995). Rumusan yang digunakan dalam pehitungannya adalah sebagai berikut:

$$
\frac{k_{h p}}{k_{a x}}=\frac{2 B^{2}}{3 R^{2}\left[\ln \left(\frac{R}{r_{s}}\right)+\left(\frac{k_{a x}}{k_{s}}\right) \ln \left(\frac{r_{s}}{r_{w}}\right)-\frac{3}{4}\right]}
$$

Setelah seluruh tahapan perhitungan dimasukkan ke dalam program Plaxis 2D dengan benar, maka program dapat melakukan perhitungan. Hasil output perhitungannya menunjukkan bahwa penurunan vertikal yang terjadi berada dibawah timbunan preloading sebesar 6,615 meter, sedangkan pada titik pemasangan settelement plate terjadi penurunan sebesar 6,404 meter. Hasilnya dapat dilihat pada Gambar 4:

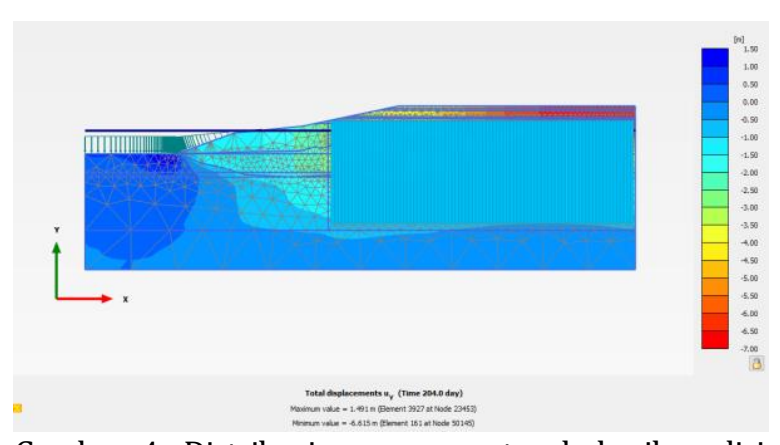

Gambar 4: Distribusi penurunan tanah hasil analisis Plaxis 2D

Tahapan permodelan dan kalkulasi pada Plaxis 3D dikerjakan sama dengan permodelan pada Plaxis 2D. Setelah tahapan Setelah keseluruhan tahapan kalkulasi selesai dikerjakan, diperoleh hasil output dari program Plaxis 3D seperti Gambar 5:

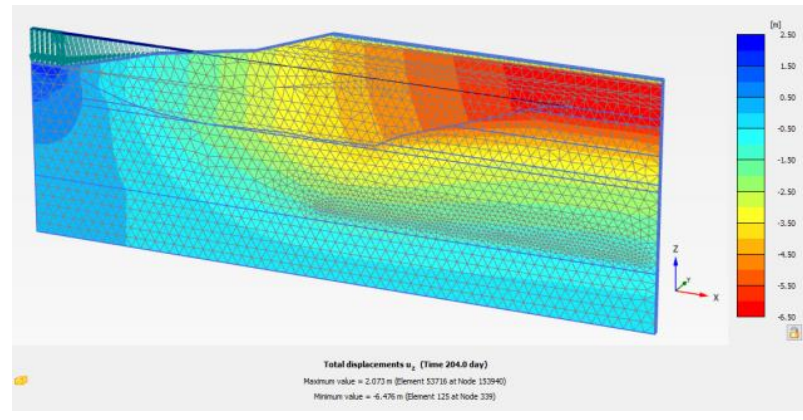

Gambar 5: Distribusi penurunan tanah hasil analisis Plaxis 3D

Penurunan tanah yangterjadi pada titik tinjauan, yaitu lokasi pemasangan settlement plate S-13, diperoleh besar penurunan tanah yang terjadi adalah sebesar 6,356 meter. 
Dengan data-data dan karakteristik tanah yang sama, namun dengan menggunakan metode analitis konsolidasi satu dimensi Terzaghi, serta metode element hingga menggunakan program Plaxis 2D dan Plaxis 3D, diperoleh bahwa hasil dari permodelan Plaxis 3D lebih mendekati penurunan aktual yang terjadi di lapangan. Hasilnya seperti tertera pada Tabel 3 berikut:

Tabel 3: Rekapitulasi hasil perhitungan penurunan tanah

\begin{tabular}{ccccc}
\hline Metode & $\begin{array}{c}\text { Aktual } \\
\text { Lapangan } \\
(m)\end{array}$ & Hasil (m & $\begin{array}{c}\text { Selisih } \\
\text { Prediksi } \\
\text { vs } \\
\text { Lapangan } \\
(\mathrm{cm})\end{array}$ & $\begin{array}{c}\text { Perbedaan } \\
\text { Penurunan } \\
(\%)\end{array}$ \\
\hline Analitis & & $-6,218$ & 10,20 & 1,61 \\
Plaxis 2D & $-6,320$ & $-6,404$ & $-8,40$ & 1,33 \\
Plaxis 3D & & $-6,356$ & $-3,60$ & 0,57 \\
\hline
\end{tabular}

\section{SIMPULAN}

Perhitungan

penurunan

konsolidasi menggunakan teori analitis relatif mendekati penurunan hasil aktual di lapangan dengan persentasi perbedaan penurunan 1,611\%. Terdapat perbedaan penurunan akibat data laboratorium tidak mewakili keseluruhan lapisan tanah. Namun jika dibandingkan dengan metode elemen hingga manggunakan Plaxis, maka hasil perhitungan menggunakan Plaxis lebih mendekati penurunan aktual lapangan. Hal ini dikarenakan pada Program plaxis sudah memperhitungkan sampai konsolidasi skunder tanah akibat deformasi partikel sedangkan teori Terzaghi hanya sampai penurunan primer. Penurunan konsolidasi menggunakan pemodelan Plaxis 3D memberikan hasil yang lebih mendekati penurunan hasil observasi di lapangan dibandingkan pemodelan Plaxis 2D. Hasil perhitungan dengan Plaxis 3D lebih akurat dibandingkan dengan hasil perhitungan Plaxis 2D, di mana persentasi perbedaan penurunan dengan tiga dimensi hanya 0,566\% dibandingkan hasil observasi lapangan, sedangkan dua dimensi 1,332\%. Pada plaxis 3D, deformasi tidak hanya memperhitungan ke arah vertikal melainkan juga lateral. Inilah yang menyebabkan plaxis 3D memiliki hasil yang lebih akurat dan menggambarkan kondisi sebenarnya lapangan.

\section{DAFTAR PUSTAKA}

Chai, J. C., Shen, S. L., Miura, N. dan Bergado, D. T. (2001), Simple Method of Modeling PVDImproved Soft Soil, Journal of Geotechnical and Geoenvironment Engineering Vol. 127, No. 11.

Chunlin li, 2013. A Simplified Method for Prediction of Embankment Settlement in Clays. Institute of Civil Engineering, Tongling University, Tongling.

Das, Braja M. 2014. Principles of Foundation Engineering Eighth Edition. Cengage Learning. Stamford

Hasbullah Nawir, Dayu Apoji, Rahmatyar Fatimatuzahro, M. Dwi Pamuji; 2012. Prediksi Penurunan Tanah Menggunakan Prosedur Observasi Asaoka, Studi Kasus : Timbunan di Bontang, Kalimantan Timur. Institut Teknologi Bandung. Bandung

Hird, C. C., Pyrah, I. C., Russel, D. dan Cinicioglu, F. (1995), Modelling the Effect of Vertical Drains in Two-dimensional finite element analyses of embankments on soft ground. Canadian Geotecnical Journal DOI:10.1139/195-077. 
Michael. (2017) Analisis Konsolidasi Tanah Lunak Menggunakan Preloading dan PVD dengan Metode Analitis dan Metode Elemen Hingga (Studi Kasus Proyek Jalan Bebas Hambatan Medan-Kualanamu KM 36+100). Repositori Institusi USU, Univsersitas Sumatera Utara, Medan

Muthing N., Zhao C., Holter R., Schanz T. (2018). Settlement Prediction for an Embankment on Soft Soil. Journal of Computers and Geotechnics. 93(2018), 87- 103.

Marfo. S.A, Appah. D, Joel. O.F. (2015). "Sand Consolidation Operations, Challenges and Remedy". University of Mines and Technology, Tarkwa, Ghana.

Ohoimas, M.Y. dan Hamdhan, I. N. (2015), Analisis Konsolidasi dengan Menggunakan Metode Preloading dan Vertical Drain pada Areal Reklamasi Proyek Pengembangan Pelabuhan Belawan Tahap II, Jurnal Institut Teknologi Nasional.Vol.1 No.1. Desember 2015.

Pasaribu, T.H. dan Iskandar, R., 2012, Analisa Penurunan Pada Tanah Lunak Akibat Timbunan (Studi Kasus Runway Bandara Medan Baru), Tugas Akhir, Medan, Jurusan Teknik Sipil Universitas Sumatera Utara

Prakoso Agung, Mukhlisin Muhammad, Raharjo Pentardi (2019). Analisis Penurunan Timbunan Tanah Silt Pada Proyek Jalan Ruas GiriwoyoDuwet Wonogiri. Jurusan Teknik Sipil Politeknik Negeri Semarang

Roesyanto, R. Iskandar, S.A. Silalahi, Fadliansyah. 2017. Soil Settlement Analysis in Soft Soil by Using Preloading System and Prefabricated Vertical Draining Runway of Kualanamu Airport. Universitas Sumatera Utara. Medan. IOP Conf. Series: Materials Science and Engineering 309 (2018)

Titi Hayati, (2019). Analisis Pengaruh Smear Zone Pada Penurunan Dan Waktu Konsolidasi Proyek Reklamasi Belawan Fase-II Dengan Plaxis 2D Dan 3D.Universitas Sumatera Utara. Medan

Wesley L. D.(2017). "Mekanika Tanah". Andi. Jakarta Yun Tae Kim, Ba-Phu Nguyen, dan Dae-Ho Yun, (2017). Analysis of Consolidation Behavior of PVDimproved ground Considering a Varied Discharge Capacity. Pukyong National University, Busan 